\title{
How Do International Non-Muslim Students at Islamic University in Indonesia Cope With the Culture Shock During Their Studies?
}

\author{
Nur Jannah Ismi Wakhidah* \\ Sekolah Pascasarjana \\ Universitas Muhammadiyah Surakarta \\ Surakarta, Indonesia \\ jannahismi96@gmail.com
}

\begin{abstract}
Study abroad is regarded as a priority factor of intercultural competence, which encourages learning of foreign cultures, and foreign language skills and obtained intercultural experience, but there are many challenges and difficulties faced by students who study abroad. This study investigates the culture shock experienced by international non-Muslim students studying at Universitas Muhammadiyah Surakarta and their strategies to cope with culture shock during their study in Indonesia. The data of the research collected through in-depth interviews with five participants who come from Laos, Thailand, Madagascar, and Zimbabwe. This is categorized as a qualitative descriptive study which aims to describe kinds of culture shock faced by international non-Muslim students, types of strategies used to cope with the culture shock and their response about Islamic universities. The results of the study showed most international students experienced culture shock in terms of language, food, weather, environment, transportation, and Islamic culture. The study also showed that almost all international students experienced homesickness.
\end{abstract}

Keywords - culture shock, intercultural competence, international student

\section{INTRODUCTION}

Based on QRank survey Universitas Muhammadiyah Surakarta (UMS) is categorized as the best Islamic university in Surakarta while according to UniRank it is placed in the top 12 best universities in Indonesia. The increase in the quality impacts on the rise of international students studying at the university. The international students in UMS are varied in terms of countries of origin, races, cultures, backgrounds, and languages. This diversity has been a challenge for them and it is difficult for them to adapt to the new environment. It also influences the pattern of their intercultural communication competence and the way they interact with students, lecturers and also local people.

The difficulties to adapt to the new environment also known as culture shock. Peeling (2000) stated that a culture shock is precipitated when one loses fluency in the familiar ways in which people interact in daily social situations, such as how to greets people, what to say in certain situations, how to react between classmates, and so on. Other symptoms of culture shock also include food of the host country, contact with members of the host country, whether of the host country and others. When experiencing culture shock, international students, especially non-Muslim students studying in UMS have to face difficulties not only in adapting to the diversity of language, weather, and food but also in dealing with the new culture in an Islamic

\author{
Hepy Adityarini \\ Sekolah Pascasarjana \\ Universitas Muhammadiyah Surakarta \\ Surakarta, Indonesia \\ Hepi.Adityarini@ums.ac.id
}

environment. Since they live abroad in a country that has different cultures with their homeland, they will try to adapt and build a strategy to cope with culture shock experienced by them. Culture shock is a condition where someone has a transition in the new environment and culture which makes her/him feel difficult. On the other side, international students also have to increase their intercultural communication skills to connect with people during their studies. Toomey and Chung (2012) introduced flexible intercultural communication which means managing cultural differences adaptively and creatively in a wide variety of situations. It can be seen that intercultural communication skill is important for a foreign student to connect with the new environment during their study at Universitas Muhammadiyah Surakarta.

In facing culture shock in an Islamic environment, International non-Muslim students have strategies to cope with it. They will try to find a way to get over with culture shock. Coping with culture shock means they have to adjust the way to respond to the new cultural environment and to establish themselves in the new environment. This study focuses to answer the following research questions:

1. what are the types of culture shock experienced by non-Muslim international students who study at UMS?

2. what are their strategies to cope with culture shock during their study at UMS?

3. what are their responses about living Islamic universities.

The discussion may be useful for international students intending to study in Indonesia who need to learn about potential culture shocks and some strategies to cope with them.

\section{LITERATURE REVIEW}

\section{A. Understanding Culture Shock}

When people come into a new environment having different cultures, habits, and social interactions, they would probably face challenges in facing the transition of diversity in the new environment. This phenomenon is usually called a culture shock. The term culture shock was coined by Oberg (1960) who describes it as a kind of anxiety resulting from losing all familiar signs and symbols of social intercourse. Toomey and Chung (2012) define culture shock as a stressful transitional period when individuals move from a familiar environment into an unfamiliar one. It can be seen that 
culture shock occurs in the transition condition which has different behavior and affects someone's daily life routine.

Wa-Mbaleka (2012) defines a culture shock as an expression of the emotional and physical difficulties that one experiences in a new culture or situation. Meanwhile, Liu Shuang, Zala Volvic and Cindy Gallois (2015) define culture shock as the feelings of disorientation and anxiety that sojourner experiences when entering a new culture. Sojourners are people who are visiting in the new environments for a long period such as students and business people. Based on the definition from experts above, it can be concluded culture shock is peoples' experience situation when feeling unfamiliar with the new culture and habit of the environment so that they have to struggle to find the way how to communicate, interact and adapt well with the new environment.

\section{B. Cause of Culture Shock}

Winkelman (1994) divided the cause of culture shock into three namely cognitive fatigue, role shock, and personal shock. Cognitive fatigue is related to the effort and attention required to understand the new culture in the new places and all of the information is very fatiguing in mental and emotional fatigue. Role shock means the loss of one's identity role in the new environment. Personal Shock is defined as an aspect of culture shock that affects personal life. Brynes (1996) defined role shock as changes in social roles and interpersonal relations affect well-being and selfconcept. Personal shock is related to losing interpersonal contact with the others, as Winkelman (1994) defined personal shock is an aspect of culture shock affecting the diverse change in the personal life of sojourners.

Here, researchers have an opinion that culture shock happened from various factors, such as food, weather, habit, and others. Rafika, Syahri, and Susanti (2018) in their study showed some aspects that caused culture shock experienced by foreign workers in Indonesia such as language, season, environment, friends at work, rules, local people, food, dress, habit, and women-men relationship. It can be concluded commonly cause of culture shock from inner and external factors. Inner factors come from mental readiness to come to the new target country. The external factors come from weather, food, environment and the other factors that can't deny by sojourners.

\section{Strategies To Cope With Culture Shock}

Sojourners who come into a new environment and experiencing culture shock will face difficulties with new foreign cultures then become frustrated and irritated with the conflict in the new environment. They are facing unfamiliar conditions and try to act and react to adjust the new foreign culture. The way how to accept challenges of culture shock is known as adjustment of culture shock. Matsumoto, Yoo, and LeRoux (2010) stated the basic need for people who come into a new environment is addressing the sense of emotional insecurity and vulnerability. The more newcomers are at managing their identity threat level, the more they able to induce effective adaptation outcomes.

It can be seen that a coping strategy with culture shock is an act and thought to adjust factors of stress from internal and external. In conclusion, coping with culture means an effort done by newcomers to manage and adjust to the new environment when facing and experiencing culture shock to reduce stress when living in a new place with different cultures.

\section{Intercultural Communication Competence}

In the development of technology and the globalization era, we are forced to communicate with people around the world with different backgrounds of cultures. Awareness of intercultural communication competence to cope with cultural diversity is important when we live in a global society. Intercultural communicative competence facilitates newcomers to be easier and familiar with cultural trends of the host culture and they can build understanding and readjustment to social expectations. It may seem that verbal exchange can keep the interplay between newbies and local people. As we interact with people from different cultures we also need intercultural communication competence so that we can communicate well with people around the world with different backgrounds. It is important to study intercultural communication competence nowadays. Toomey and Chung (2012) stated that the study of intercultural communication is about the study of communication that involves, at least in part, cultural group membership differences. They also defined intercultural communication as a symbolic exchange process whereby individuals from two or more different cultural communities attempt to negotiate shared meanings in an interactive situation within an embedded societal system. Intercultural communication also refers to the communication between individuals who might differ in ethnic, socioeconomic status, age, gender, and lifestyle.

\section{RESEARCH METHODOLOGY}

The type of this research is a descriptive qualitative study that refers to the method to formulate the conclusion by collecting, classifying, and interpreting the data. Qualitative data in this study were collected through in-depth interview to explore about culture shock which experienced by NonMuslim international student at UMS. There are five international students as respondents: two students from Laos, one from Thailand, one from Madagascar, one from Zimbabwe. The questions of interviews explore the types of culture shock that international non-Muslim students experienced, strategies to cope with culture shock and responses related to living and studying at an Islamic university. After collecting data through interviews then the researchers analyze the transcript of the interview based on types of culture shocks namely language, food, weather, environment, transportation, homesickness, and Islamic culture shock, including their strategies to cope with the culture shock. The data are presented in the narrative descriptive and the original answer from the participant.

\section{RESUlTS AND DISCUSSION}

From the transcript of the interview with two students from Laos initialed Mr. P and Mr. K, one from Thai initialed Mr. M, one from Madagascar initialed Mr. R and one from Zimbabwe initialed Ms. C, the study found causes of culture shock and their strategies to cope with culture shock experienced by International non-Muslim student who 
studies at Islamic University. The results are explained below:

\section{A. Cause of Culture Shock}

\section{1) Language}

The first difficult thing for international students who come to Indonesia is the Indonesian language or also known as Bahasa. Almost all respondents said that they have difficulties to communicate with local people because they cannot speak Bahasa and not all Indonesians can speak English. P, K, R, and C stated that Bahasa is difficult to handle when living in Indonesia. $\mathrm{P}$ explained about his difficulties in Bahasa: "Bahasa is difficult for me because I didn't know at all about Bahasa when the first time comes in Solo. I used my dictionary if I want to communicate with local people”. C also added that she can't communicate well with local people in Solo because of Bahasa "I can speak English in Bandung but in Solo im not. Cause people here can't speak English'.

\section{2) Food}

This study showed mostly international nonMuslim students have difficulties to get appropriate food that suits their taste. $\mathrm{P}, \mathrm{K} \mathrm{R}$, and $\mathrm{C}$ said that food is difficult to adjust in the early year they came to Solo. $\mathrm{R}$ explained his culture shock with food in Indonesia :

"I don't really like Indonesian fried food. Commonly Indonesian food is fried and spicy I don't really like it because it is unhealthy actually. I used to eat Fresh vegetables in Madagascar. I'm getting fat now because of Indonesian food haha"

$\mathrm{C}$ also said the challenges with Indonesian food as what follows:

"Food? I can't buy in a local restaurant here because their food is spicy and too sweet. I have to go to pizza hut and KFC and it is expensive. Commonly, my food in Zimbabwe is salt. The way the Indonesian food cook is also different from Zimbabwe. In Zimbabwe, we boil it and Indo fried it."

\section{3) Weather}

Some respondents have difficulties with the weather in Solo, especially R and C. R explained, "Weather for a couple of days in the morning is too cold in solo, but in the afternoon compare to my country, here is hotter". C also added the problem with the weather in Indonesia by saying "So so hot...very hot. Your summer is too hot and when the rainy season the rain is too much. Sometimes here is flood right? because of the rainy season. Argghh rainy. That's the reason I don't wanna back to Indonesia”.

\section{4) Environment}

One of the causes of culture shock also is related to the new environment. Mostly respondents complained about the smoking habits of Indonesian people. K, P, and $\mathrm{M}$ shocked by the Indonesian smoking habit in a public place. M explained "I have little problem in smoking because they smoke freely in a public place. In Thai, we have a long campaign to smoke in the smoking area, not in public place" then, $\mathrm{K}$ also added, "I feel angry when Indonesian people smoking in public place and they don't care with the others".

\section{5) Transportation and Traffic in the City}

This study also found the culture shock which is related to transportation and traffic in the city. Three international students namely $\mathrm{R}, \mathrm{P}$ and $\mathrm{C}$ complained about the traffic in the city and two of them complained about the public transportation in Solo. R said "The problem here is about public transportation. I can't go anywhere especially I don't have a motorcycle then I have to walk very far to go to bus station. I Have to wait one hour to get bus. Cause in my country the government prioritizing public transportation, so it is very different when I came here." Explaining about traffic in Solo, P said "There are so many motorcycles here and it looks so crowded and also the road system is different. In Indonesia, you ride on the left side but in Laos, you ride on the right side". C also complained about traffic jams in the city, she said "I never seen kind of that in my life in Zimbabwe if we want to go somewhere for example 15 kilometers mostly it takes only 15 minutes but in here it takes one hour, and we have to be patient. I don't know arghh".

\section{6) Homesickness}

Almost all respondents experienced homesickness commonly they miss their food, meanwhile, they can't found in Indonesia. R, C, K, and P experienced homesickness. P said "sometimes I miss my family but it is no problem because I can call them. Maybe next year ill back to Laos. But the big problem when I miss my Laos food, the seasoning is different from Indo" C also added similarly such as missing her country food "I miss my Food a lot. The big difference is about corn. Indonesia corn is sweet and in Zimbabwe the corn it just white corn. Sometimes if I miss Zimbabwe food I just go to an expensive restaurant I eat as much I want"

\section{7) Islamic Culture}

a) Adzan

The majority of people in Solo are Muslim. Related to living in an Islamic environment, some aspects can be the cause of culture shock for international students. One of them is adzan (sounds of Muslim prayer). For the first time, $\mathrm{C}, \mathrm{P}$, and $\mathrm{K}$ were shocked by the adzan sound. K said "one night I can't sleep at 4 am I wake up because of sound adzan. I never heard before, am surprised. I think it is a sign of a tsunami or earthquake. I ask to owner of my dormitory, is there any something happen then he try to explain me about what adzan is hahaha." $\mathrm{C}$ has almost the same experience, she explained "I don't even know adzan in the first time I came in Indonesia. First day, I can't sleep at all because my dorm is near mosque then I heard adzan for the first time, I just questioning and I 
think maybe only that day and tomorrow would not happen, but the next day it happened again, then oo... I decided lets move so I shifted my dorm in the next day."

\section{b) Ramadan}

The other Islamic culture is about Ramadan, a time when all Muslims have to fast in one month full, started from morning until evening. P, K, R from and $\mathrm{C}$ shocked by the condition during Ramadan in Indonesia as common people didn't eat at all and local students back to their hometown for preparing Eid Fitri. R explained "it is hard for me during Ramadan, because I stay alone actually during Ramadan and difficult for me to have food cause commonly local restaurants are closed" $\mathrm{K}$ his experience during Ramadan "I should buy the food far away or in supermarket it's difficult for me. I am getting thin during Ramadan, but after Ramadan I'm getting fat"

\section{B. Strategy to Cope with Culture Shock}

To be able to overcome all challenges of culture shock there are some strategies found in this study:

\section{1) Communicate with Local People}

$\mathrm{P}, \mathrm{K}, \mathrm{R}$, and $\mathrm{C}$ use communication as a strategy to overcome culture shock experienced by them. They tried to communicate with local people, hoping they could easily adapt to the new life during their studies. C explained "I used to be friendly, always asking and talk to everyone. I remember when someone invites me to jalan-jalan (picnic) to near Wonogiri because I try to communicate friendly with local people here." $\mathrm{K}$ also adds "I always communicate with my friends in dorm, and they always help me to give information such as to learn Javanese language"

\section{2) Build Connection with Local Friends}

The second strategy is building and expanding connections with local people. This strategy is used by $\mathrm{R}, \mathrm{K}$ and $\mathrm{C}$. R explained "I have wonderful friends here they invite me to go to their home. They help me a lot during my study here." Another explanation related to expanding connection with local people is explained by C, "I'm good to everyone, I try to follow what they do if they smile at me so I smile back to them I love Solonese people. I like them so much. One thing that makes me comfortable is when I talk they can understand. So far Solonese people are friendly, helpful, and kind."

\section{3) Learning and Understanding}

The third strategy the researchers found is trying to learn and understand the new culture in Indonesia. C from Zimbabwe, Mr. R from Madagascar, Mr. P and Mr. $\mathrm{K}$, and $\mathrm{M}$ use this strategy to overcome culture shock in Indonesia. K explained "Ya...I try to understand and learn everything from my friend. Try to find someone to give me information...."

\section{Responses About Studying at Islamic University}

The last discussion is related to general comments and responses of the international non-Muslim students studying at an Islamic university. All of the respondents mostly enjoy studying at UMS, and they feel comfortable with friends and lecturers at UMS. They explained it below:

"For me in Islamic university, I feel... it's okay, I'm Buddhist I don't trouble you and you don't trouble me, I don't have negative point with Islam. I can live with Muslims. I learn a lot during my study here. I finished study class preparation for study Bahasa Indonesia. The facility here and textbook and other were good. About the lecturer, They are very kind. They help me to get information and everything. The quality of teacher is very good in teaching us, also the techniques, so I can understand but not at all but If I don't understand I try to request to lecturers to explain to me until I understand"'d (K from Laos)

"UMS is very good. Because... when I went to other universities so many my international friends said that the university sometimes difficult for a foreign student, but so far I stayed here everything is okay. The lecturers also kind and helpful they help me a lot" (P from Laos)

\section{CONCLUSION}

Based on the findings, it indicates that mostly international non-Muslim students experienced culture shock. From the result, some points can be drawn. First, mostly international students participating in the study experienced culture shock in terms of language, food, weather, environment, and transportation. Second, Almost all international students in this study experienced homesickness especially missing the food. Third, the most difficult things to handle are the language and food. Fourth, Almost all participants of the study experienced Islamic culture shock because they live as a minority in an Islamic environment. Finally, this study also showed that traveler doesn't have difficulties to handle new culture.

\section{REFERENCES}

Brynes. F, 1996Role shock :An occupational hazard of American technical assistants abroad. Annals of the American Academy of Political and Social Science, pp. 95-108,

Liu Shuang, Zala Volvic, and Cindy Gallois, Introducing intercultural communication, SAGE Publications: London, 2015.

Matsumodo D, Yoo S.H, and LeRoux J.A, Emotion and intercultural adjustment in D Matsumudo (Ed.), APA handbook of intercultural communication (pp. 23-39), Washington DC; american Psyhcological Association, 2010.

Oberg.K, Culture Shock: Adjustment to new cultural environments. Practical Anthropology. 1960

Peeling Andrew C, Culture shock of international students in Canada, University of Lethbridge, Lethbridge Alberta, 2000.

Rafika. D.A, Syahri I and Susanti.R, Culture shock experienced by foreign workers, Archieves of business research Vol.6 No.4, April, 2018.

Ting-Toomey Stella and Leeva C. Chung, Understanding Intercultural Communication, Oxford University Press, New York, 2012.

Universitas Muhammadiyah Surakarta University Reviews. .4icu.org/id/ Accessed 12 October 2019. 
Wa-Mbaleka Safary, Coping with culture shock in second language settings a phenomenological study in the Philippines, Vol. 4, October 2012.
Winkelman. Michael James, Culture shock and adaptation, Article in journal counseling and development, 1994. 